УДК 373.5.016:30]:004.9

Гриценчук Олена Олександрівна

науковий співробітник Інформаційно-аналітичного відділу педагогічних інновацій Інститут інформаційних технологій і засобів навчання НАПН України, м. Київ, Україна

gritsenchuk@iitta.gov.ua

\title{
ІНФОРМАЦІЙНО-КОМУНИКАЦІЙНА КОМПЕТЕНТНІСТЬ УЧНІВ ЯК АСПЕКТ МОНІТОРИНГУ (ДОСВІД МІЖНАРОДНИХ ПОРІВНЯЛЬНИХ ДОСЛІДЖЕНЬ ОЕСD ТА IEA)
}

\begin{abstract}
Анотація. У статті висвітлено досвід міжнародних організацій: Міжнародної асоціації оцінювання навчальних досягнень (The International Association for the Evaluation of Educational Achievement - IEA) та Організації з економічного співробітництва та розвитку OECP (Organisation for Economic Cooperation and Development - OECD) щодо моніторингових досліджень інформаційно-комунікаційної компетентності (IКкомпетентності) учнів загальноосвітніх навчальних закладів; подано аналіз загальних підходів до моніторингових досліджень ІК-компетентності учнів у країнах Європи на сучасному етапі. Визначено особливості, загальні тенденції та перспективні шляхи розвитку.
\end{abstract}

Ключові слова: інформаційно-комунікаційна компетентність (ІК-компетентність) учнів; моніторинг; моніторинг ІК-компетентності; середня освіта.

\section{1. ВСТУП}

Постановка проблеми. На шляху побудови i розвитку інформаційного суспільства більшість країн сьогодні визнають важливість підготовки кадрів у галузі інформаційних і комунікаційних технологій (IКT). Провідна роль у цьому процесі належить ланці загальної середньої освіти, де закладаються основи знань, умінь та навичок, формуються і розвиваються ціннісні орієнтації учнів з IКТ, тобто формується компетентна особистість, що може реалізувати себе у сучасному світі. Слід зазначити, що у зарубіжних країнах існує певна різниця у начальних планах, методиках викладання, підходах, ресурсах і та ін., зокрема у галузі ІКТ. Інтеграційні процеси, що відбуваються у сучасному світі, в значній мірі впливають на освіту, вимагаючи узгодження підходів до розвитку змісту освіти, оцінювання навчальних досягнень і та ін. Міжнародною педагогічною спільнотою піднімається питання щодо розроблення уніфікованої рамки, базових стандартів з ІКТ, що посприяють розвитку національної освітньої політики, забезпеченню якісного рівня освіти. Ефективним інструментом для цього є міжнародні моніторингові дослідження.

Аналіз останніх досліджень і публікацій. Проблему моніторингу якості освіти досліджували у своїх роботах Байназарова О.О, Бурда I.М., Євтух М.Б., Кремень В. Г., Локшина О.І., Луговий В.І., Лукіна Т.О, Ляшенко О. І., Ничкало Н.Г., Савченко О. Я., Сухомлинська О.В. [1;5], аспекти теорії і практики моніторингу рівня навчальних досягнень у галузі ІКТ грунтовно розглядалися у роботах Бикова В.Ю, Жука Ю. О., Лапінського В.В., Морзе Н.В., Кузьминської О.Г., Овчарук О.В. та ін. [6;9]. Основні підходи до стандартизації інформаційно-комунікаційної компетентностей у системі загальної середньої освіти висвітлені у дослідженнях Бикова В.Ю., Богачкова Ю. М., Литвинової С. Г., Овчарук О. В., Спіріна О. М., Хуторського А.В. [11] та ін. Деякі питання теорії та практики моніторингу ІК-компетентності учнів потребують більш детального вивчення. 
Метою статті $є$ дослідження досвіду міжнародних організацій Міжнародної асоціації оцінювання навчальних досягнень (The International Association for the Evaluation of Educational Achievement - IEA) та Організації 3 економічного співробітництва та розвитку ОЕСР (Organisation for Economic Cooperation and Development - OECD) з проблеми моніторингу ІК-компетентності учнів європейських країн.

\section{2. МЕТОДИ ДОСЛІДЖЕННЯ}

Дослідження проводилось в рамках науково-дослідної роботи «Формування інформаційно-комунікаційних компетентностей учнів у контексті євроінтеграційних процесів в освіті» Інституту інформаційних технологій і засобів навчання НАПН України. Основні методи, що застосовані у дослідженні: аналіз науково-педагогічної літератури, нормативно-правових міжнародних та вітчизняних документів, джерел, представлених в мережі Інтернет з проблеми міжнародних моніторингових досліджень IК-компетентності учнів в європейських країнах; дослідження та узагальнення міжнародного та вітчизняного педагогічного досвіду.

\section{3. РЕЗУЛЬТАТИ ДОСЛІДЖЕННЯ}

Як зазначається у «Національній стратегії розвитку освіти в Україні на 2012 2021 роки», серед напрямів розвитку державної освітньої політики, стратегічними визначені інформаційно-ресурсне забезпечення освіти i науки та забезпечення національного моніторингу системи освіти. За визначенням академіка Ляшенка О. I. освітній моніторинг «це система заходів щодо збирання, опрацювання, аналізу та поширення інформації з метою вивчення й оцінювання стану функціонування певного суб'єкта освітньої діяльності чи освітньої системи загалом та прогнозування їх розвитку на основі одержаних даних і виявлених тенденцій і закономірностей» $[7,26]$. Провідними українськими науковцями визначено роль моніторингових досліджень як дієвого механізму, що забезпечує управління якістю освіти. На думку дослідників А.Тайджмана та Т. Невіла Послтвейта об'єктом моніторингового дослідження можуть бути і ресурси, і процеси, і результати освітнього процесу [8]. Одним 3 яких є моніторинг ІК-компетентності учнів, як результату навчальної діяльності у контексті компетентісно-орієнтованого спрямування освітньої політики.

Проблеми освітнього моніторингу у галузі ІКТ висвітлено в працях вітчизняних науковців Бикова В.Ю, Богачкова Ю.О, Жука Ю.О, Кузьминської О.Г., Морзе Н.В. та ін. Дану проблему вивчали зарубіжні дослідники Андерсон Р., Блум Б., Гопкінз Д, Козма Р., Мак-Гінн Н., Невілл Послтвейт Т., Пелгрум У., Раймерз Ф., Тайджман А, Тайлер Р., Торндайк Р., Х'юсен Т. ті ін.

Компетентісне спрямування освіти сьогодні є одним із напрямів курсу освітньої політики як у європейських країнах, так і в Україні. Вітчизняні законодавчі та нормативні документи, грунтуючись на засадах компетентісного підходу в освіті, серед інших ключових компетентностей визначають ІК-компетентність як таку, що має бути сформована в учня у процесі навчання. Предметна (галузева) компетентність освітньої галузі «Технології», також має назву «інформаційно-комунікаційна» предметна компетентність. Державним стандартом початкової загальної освіти, що впровадився у 2012/2013 навчальному році, зазначено закладення основ IК-компетентності [2]. У Державному стандарті базової і повної загальної середньої освіти, що впроваджується у 2013/2014 році у 5-х класах, ІК- компетентність визначається як «здатність учня 
використовувати інформаційно-комунікаційні технології та відповідні засоби для виконання особистісних і суспільно значущих завдань», а також зазначено, що «формування інформаційно-комунікаційної компетентності учнів, зміст якої $\epsilon$ інтегративним, відбувається у результаті застосування під час вивчення всіх предметів навчального плану діяльнісного підходу. Навчальними програмами обов'язково передбачається внесок кожного навчального предмета у формування зазначеної компетентності» [3].

Так на думку О.М.Спіріна «комп’ютерна компетентність», «інформаційнокомп'ютерна компетентність», «інформаційно-технологічна компетентність», «інформаційно-комунікаційна компетентність» синонімічні до терміну «інформаційнокомунікаційно-технологічна компетентність» або «IКТ - компетентність» і визначає іiі як «підтверджену здатність особистості автономно і відповідально використовувати на практиці інформаційно-комунікаційні технології для задоволення власних індивідуальних потреб і розв'язання суспільно значущих, зокрема професійних, задач у певній предметний галузі або виді діяльності» $[11,46]$. За визначенням О.В. Овчарук ІК-компетентність слід розуміти як «сукупність знань і розуміння, умінь і навичок, а також особистісних ставлень і ціннісних орієнтацій людини у галузі ІКТ та здатність автономно і відповідально демонструвати їх для практичної, професійної діяльності та навчання продовж життя» $[11,46]$.

Міжнародною педагогічною спільнотою визначено певні знання, уміння, навички, особистісні ставлення, ціннісні орієнтири, що дозволять молодій людині бути компетентною у галузі ІКТ, однак слід зазначити, що їх перелік постійно уточнюється. I саме поняття «ІК-компетентність» знаходиться у дискусійному полі як для зарубіжних, так і вітчизняних освітян. Досліджуючи зарубіжні джерела, ми зустрічаємо поняття і терміни, які використовуються міжнародною педагогічною спільнотою, що визначають знання, уміння, навички, особистісні ціннісні судження у галузі IКТ. Наведемо основні терміни та дамо деякі визначення: цифрова грамотність (digital fluency, digital literacy), IКT навички (ICT skills), IКТ-грамотність (ICT literacy), IКTкомпетентність /компетентність /компетентності (ICT-competence / competency / competencies), медіаграмотність (media literacy), інформаційна грамотність (information literacy), комунікаційна компетентність (communication competence).

Навички IKT (ICT skills): здатність використовувати інформаційні і комунікаційні технології для певної мети ефективно, критично і продуктивно [17].

3 прийняттям Європейською комісією у 2010 році так званого «Цифрового порядку денного» (Digital agenda) було окреслено цілі, однією із яких є підвищення у громадян європейських країн рівня володіння IКТ навичками (ICT practitioner skills), у тому числі цифровою і медіа грамотністю (digital/ media literacy), е-навичками ( eSkills).

Mediazpaмотність (media literacy): навички і знання, що дозволяють ефективно і безпечно використовувати засоби масової інформації. Медіаграмотність надає можливість здійснювати усвідомлений вибір, зрозуміти сутність змісту і сервісів, та використовувати повний спектр можливостей, що пропонують нові комунікаційні технології [13].

Iнформаційна грамотність (information literacy): оперативне i ефективне знаходження інформації, критичне і компетентне іiі оцінювання. Використання та управління інформацією точно i творчо для розв'язання питання та вирішення поточних проблем, керування інформаційними потоками із різних джерел та фундаментальне розуміння етичних i правових питань, пов'язаних 3 доступом та використання інформації [16].

Коло термінів і понять галузі ІКТ, що стосуються освіти, досить широке. Комунікаційні процеси у сучасному суспільстві відбуваються одночасно у різних 
форматах: текстовому, аудіо і відео, реальному, віртуальному. Зважаючи на це, спостерігається тенденція до конвергенції понять. На думку Альберта К. Букхорста, необхідно об'єднати терміни «Інформаційна грамотність» та «Медіаграмотність». Німецькі дослідники Йоахим Гриесбаум, Рейнер Кухлен доводять доцільність поєднання понять «Інформаційна грамотність» та «Комунікаційна компетентність» у IК-компетентність. За визначенням австралійських дослідників Дж. Фрайлон та Дж. Ейнлі «Комп'ютерні та інформаційна грамотність» (Computer and information literacy) це здатність людини використовувати комп'ютер для навчання, роботи (діяльності, творчості) і спілкування з метою ефективного залучення ії до життя вдома, в школі, на робочому місці і в суспільстві [15].

Отже, погоджуючись 3 думкою зарубіжних i вітчизняних науковців щодо визначень і тлумачень, спираючись на нормативно-правові документи, спробуємо уточнити поняття «моніторинг ІК-компетентності учня», що $\epsilon$ системною $\mathrm{i}$ систематичною процедурою, до якої відносяться: спостереження, збір даних, порівняння, а також оцінювання рівня навчальних досягнень учні в галузі IКТ, як результату діяльності освітньої системи, інтерпретація, оприлюднення, розповсюдження та прогнозування результатів якого будуть використані для надання рекомендацій щодо розвитку освітньої політики у напрямку формування і розвитку ІКкомпетентності учня.

Європейські країни розвивають національні системи моніторингу. За даними Евридайс (2009-2010рр.) серед індикаторів вимірювання освітньої політики одним із показників був показник щодо проведення моніторингу рівня навчальних досягнень учнів. Механізм моніторингу впроваджується у 25 країнах-учасницях: у 17 країн він використовується для дослідження, а у 8 країнах знаходиться в стані розробки. Варто, зазначити, що моніторинг ІК-компетентності учнів, явище відносно нове, і знаходиться у стадії розвитку.

Національні системи моніторингу отримують інформацію щодо розвитку освіти в певній країні, однак, на рівні порівняння систем освіти у різних країнах, виникає потреба у міжнародних дослідженнях для більш об'єктивної інтерпретації результатів та розвитку національної освітньої політики. В умовах європейської інтеграції край важливою стає співпраця країн, і в цьому контексті набувають актуальності міжнародні моніторингові дослідження. Останнім часом помітно збільшилася зацікавленість та участь у міжнародних порівняльних освітніх моніторингових дослідженнях, про що свідчить зростання кількості країн, які беруть в них участь. Як зазначається експертами освітньої політики ПРООН, розвиток сучасної системи моніторингу в Україні має відбуватися у поєднанні 3 міжнародними моніторинговими програмами ОЕСР Організація Економічного Співробітництва та Розвитку (OECD - Organisation for Economic Co-operation and Development), Міжнародною асоціацією оцінювання навчальних досягнень (IEA - The International Association for the Evaluation of Educational Achievement) тощо.

Міжнародна асоціація оцінювання навчальних досягнень (International Association for the Evaluation of Educational Achievement - IEA, http://www.iea.nl/ ) серед інших проводить міжнародні масштабні порівняльні дослідження у галузі ІКТ, починаючи із 1989 року. Останнім є дослідження, що триває - ICILS 2013 (International Computer and Information Literacy Study - Міжнародне дослідження комп'ютерної і інформаційної грамотності), розпочате у 2010 році. Метою ICILS 2013 є визначення рівня і стану сформованості комп'ютерної та інформаційної грамотності учнів, здатності застосовувати комп'ютери та ІКТ для навчання і життя, з'ясування рівня готовності до життя у інформаційному суспільстві. Дослідження, що буде завершене наприкінці 2013 року, має дослідити і висвітлити такі питання: 
- які розбіжності у рівні комп'ютерної та інформаційної грамотності учнів в різних країнах та у межах однієї країни;

- які фактори впливають на комп'ютерну та інформаційну грамотність учнів: загальний підхід до навчання комп'ютерній та інформаційній грамотності; методики навчання; особисте ставлення вчителя та компетентність у IКТ; доступ школи до IКТ; професійна підготовка і розвиток вчителя; участь школи у реалізації програм з навчання комп'ютерній та інформаційній грамотності;

- які індивідуальні особливості впливають на сформованість комп’ютерної та інформаційної грамотності учнів: які відмінності мають ці особливості у різних країнах, а також у межах однієї країни; у якій мірі корелюється результат вимірювання з самооцінюванням; якою $є$ ця кореляція між країнами і групами учнів;

- які особисті і соціальні аспекти (гендерний, соціально-економічний, мовний та ін.) пов'язані з комп'ютерною та інформаційною грамотністю.

Міжнародною педагогічною спільнотою визначається два підходи до вимірювання навчальних досягнень у галузі IКТ. Перший полягає у вимірювання навчальних досягнень у певній предметній галузі з використанням IКТ. Такий підхід не дає можливості виокремити результати навчальних досягнень як 3 навчального предмету дослідження (начальної галузі), так i 3 галузі IКT, він передбачає нероздільність досягнень. В основі другого підходу лежить вимірюванні досягнень у галузі ІКТ як дискретної галузі навчання. Цей підхід передбачає, що навчальні досягнення учнів з ІКТ мають бути більш загальними, ніж ті, що необхідні для тієї чи іншої дисципліни і включати набір знань, умінь, навичок та ставлень у галузі ІКТ, які легко адаптуються до нових умов.

Міжнародне дослідження комп’ютерної і інформаційної грамотності ICILS 2013 обрало другий підхід для моніторингу. Наприклад, оцінювання електронного читання може бути сфокусоване на тому, як учень зрозумів прочитаний текст, знайшов та інтерпретував інформацію, подану в тексті. У дослідженні комп'ютерної і інформаційної грамотності учнів цифрові тексти, звичайно, також використовуються, але 3 іншою метою. При читанні увага може бути зосереджена на визначенні вірогідності, точності, безпечності інформації, учень має знати про роль, яку може відігравати текст та ін. Щодо математичної грамотності, IКT, приміром, використовують для малювання графіків, побудови функцій, створення тривимірних об'єктів і та ін. При моніторингу комп' ютерної і інформаційної грамотності учню може бути надана таблиця, за даними якої він має побудувати діаграму з метою включити їі у звіт.

Комп'ютерна і інформаційна грамотність (Computer and Information Literacy - CIL) [15] визначається фахівцями ICILS як здатність особистості використовувати комп'ютер для дослідження, передавання знань $і$ спілкування з метою ефективної участі у особистому, шкільному, професійному $i$ суспільному житті. ICILS запропонована концептуальна структура комп'ютерної і інформаційної грамотності (таб.1), що складається із 2-ох стандартів.

Таблиия 1.

Концептуальна структура комп'ютерної і інформаційної грамотності (ICILS)

\begin{tabular}{|l|l|c|}
\hline $\begin{array}{l}\text { Стандарт 1 } \\
\text { Збирання і управління інформацією }\end{array}$ & $\begin{array}{l}\text { Кількість } \\
\text { тестових } \\
\text { завдань }\end{array}$ & $\begin{array}{l}\text { Кількість } \\
\text { балів }\end{array}$ \\
\hline $\begin{array}{l}\text { Аспект } 1.1 \\
\text { Знання про комп'ютер і розуміння його використання }\end{array}$ & 12 & 12 \\
\hline
\end{tabular}




\begin{tabular}{|c|c|c|}
\hline $\begin{array}{l}\text { Аспект } 1.2 \\
\text { Доступ до інформаиії та ї̈ оцінка }\end{array}$ & 10 & 14 \\
\hline $\begin{array}{l}\text { Аспект } 1.3 \\
\text { Управління інформаиієюю }\end{array}$ & 5 & 6 \\
\hline Разом (Стандарт 1) & 27 & 32 \\
\hline $\begin{array}{l}\text { Стандарт } 2 \\
\text { Створення та обмін інформацією }\end{array}$ & & \\
\hline $\begin{array}{l}\text { Аспект } 2.1 \\
\text { Обробка інформащіï }\end{array}$ & 16 & 23 \\
\hline $\begin{array}{l}\text { Аспект } 2.2 \\
\text { Створення інформації }\end{array}$ & 15 & 23 \\
\hline $\begin{array}{l}\text { Аспект } 2.3 \\
\text { Обмін інформацією }\end{array}$ & 8 & 12 \\
\hline $\begin{array}{l}\text { Аспект } 2.4 \\
\text { Користування безпечною і надійною інформачією }\end{array}$ & 14 & 15 \\
\hline Разом (Стандарт2) & 53 & 73 \\
\hline
\end{tabular}

Інструментами Міжнародного дослідження комп'ютерної та інформаційної грамотності ICILS $2013 \epsilon$ :

- міжнародний тест для учнів, що складається з набору комп'ютерно базованих валідизованих питань і завдань, які призначені для вимірювання комп'ютерної та інформаційної грамотності;

- опитувальник для учнів, що містить комп'ютерно базовані запитання, які визначають особисті і соціальні аспекти, доступ до IКТ, досвід, користування, знайомство з IКТ у школі і дома, а також збирає інформацію щодо особистісного ставлення учня до використання IКТ;

- опитувальник для вчителя 3 будь-якого предмету у цільовому класі, спрямований зібрати базову інформацію про викладача, відомості щодо користування IКТ. Анкета містить пункти, у яких вчитель має оцінити свою впевненість у використанні комп'ютеру у процесі викладання, повідомити про фактичне використання комп'ютеру i висловити своє ставлення до використання комп'ютерів у процесі навчання та викладання;

- анкета для керівників шкіл, що беруть участь у дослідженні, яка призначена для отримання інформації про школу щодо застосування IКТ у процесі викладання і навчання, а також висвітлює аспекти управління IКТ у школі;

- анкета для вчителів-координаторів з ІКТ, які беруть участь у моніторингову дослідженні, призначена для збору інформації про ресурси та IКТ підтримку в школі;

- опитування національного рівня, виконане фахівцями науково-дослідних інституцій кожної країни. Опитування збирає інформацію про структуру системи освіти, місце освіти щодо комп'ютерної і інформаційної грамотності учнів, вчителів, керівників шкіл в національному змісті освіти і освітній політиці, ініціативи та забезпечення ресурсами, що пов'язані з ІКТ. Отримані дані мають надати опис контексту для освіти щодо комп'ютерної i інформаційної грамотності в кожній країні, а також інтерпретацію результатів анкетування учнів, шкіл і вчителів.

Однією із міжнародних ініціатив щодо моніторингових досліджень є Міжнародна програма оцінювання навчальних досягнень PISA (Programme for International Student 
Assessment), яку реалізує ОЕСР - Організація з економічного співробітництва та розвитку (OECD - Organisation for Economic Co-operation and Development, www.oecd.org), що реалізується за трьома напрямами «грамотність читання», «математична грамотність» та «природнича грамотність». Напрями моніторингу PISA не фокусуються на вимірюванні рівня знань і навичок у галузі IКТ, однак, слід відзначити загальний підхід програми до розуміння важливості вивчення і висвітлення спектру проблем, які стосуються впровадження інформаційно-комунікаційних технологій у освіту для навчання впродовж життя, зокрема, ІК-компетентності, як складової предметних компетентностей, що відображено у аналітичних документах, звітах і дослідженнях.

Сьогодні, коли розвиток освіти зарубіжних кран відбувається з застосуванням компетентісного підходу, до складової поняття як природничої, так і математичної компетентності також належать навички використання сучасних технічних засобів, пов'язаних 3 інформаційними технологіями; грамотність читання стосується грамотності читання як друкованих так і цифрових текстів. Визначення змісту поняття IKT-грамотності (ICT literacy), як зазначається у документах PISA, визначена об' єктом дослідження програми, і розуміється як «зацікавленість учня, його особисте ставлення та здібності щодо використання цифрових технологій і засобів комунікації, можливість доступу, керування, інтегрування та розвитку інформації, набуття нових знань і співпраці із іншими членами суспільства 3 метою ефективної участі у житті суспільства» [21].

Один із аспектів програми PISA 2000 року був присвячений вивченню використання комп'ютера та визначення його ролі у навчанні. Зазначаючи необхідність набуття знань та навичок у галузі IКТ для навчання та для дорослого життя, програмою проводилося опитування. У ньому взяли учать 20 із 32 країн учасниць програми PISA: Австралія, Бельгія, Данія, Ірландія, Канада, Люксембург, Мексика, Нідерланди, Німеччина, Нова Зеландія, Норвегія, США, Чеська Республіка, Швейцарія, Швеція, Угорщина, Фінляндія та 4 крани, що не були членами ОЕСР - Бразилія, Ліхтенштейн, Литва та Росія [18]. Отримані результати визначили, що в середньому зацікавленість у використанні комп'ютера у навчанні виявили 60 відсотків опитаних учнів, які працюють за комп'ютером майже кожного дня, 42 відсотки учнів є користувачами Інтернету і 30 відсотків користуються інформаційно-комунікаційними технологіями для навчання. Не зважаючи на різнорідність показників, за результатами програми PISA експерти зробили висновок про те, що IКТ стали інструментом для учнів у навчанні.

Згідно результатів досліджень попередніх років, 3 огляду на недостатню інформацію щодо рівня грамотності учні в галузі ІКТ та важливість ролі ІКТ у освітньому процесі та житті, Організацією економічного співробітництва та розвитку було прийняте рішення визначити роль та місце ІКТ у моніторингових дослідженнях. У 2003 році робочою групою експертів Освітньої служби тестування США (ЕTS Educational Testing Service) у співпраці з Австралійською радою досліджень в галузі освіти (ACER- Australian Council for Educational Research) [14] було розроблено завдання, які охоплюють спектр складових IКТ і структуруються за галузевими та процесуальними компонентами [Таблиця 2].

Табличя 2.

\begin{tabular}{|lcccccc|}
\hline & Доступ & Користування & Інтеграція & Оцінка & Конструювання & Комунікація \\
\hline Е-пошта & + & + & & & & \\
Бази даних & & + & + & & & \\
Веб абстрактні & & & + & + & + & + \\
Веб пошукові & + & + & + & + & + & + \\
Симуляціїі & + & + & + & + & + \\
\hline
\end{tabular}


Наголошуючи, що ІК-компетентність є складовою ключових компетентностей, країни-учасниці ОЕСР прийшли до думки, що визначення рівня володіння навичками в галузі IКТ має стати одним із основних фокусів дослідження PISA. Дані рекомендації надали можливість розробляти та адаптувати інструментарій моніторингових досліджень, враховуючи ІКТ складову. На розв'язання завдання, яким чином і які саме знання та навички галузі IКТ можна застосовувати у тестових завданнях, був спрямований пілотний проект, який було вирішено розпочати у трьох країнах. Таким чином, моніторингове дослідження 2006 року, у якому брали участь Данія, Ісландія і Корея, що вимірювало природничу компетентність учнів, набуло нової складової: Комп'ютерно-базовані досягнення природничої грамотності (Computer-based assessment of Scientific Literacy - CBAS) [19].

Сьогодні Міжнародна програма оцінювання навчальних досягнень учнів - PISA активно впроваджує комп'ютерні тести у своїх моніторингових дослідженнях. Інновацією програми PISA 2009 року, що проводила вимірюванні навчальних досягнень учнів 3 читання, була розробка комп'ютероно-орієнтованих тестів та вимірювання навчальних досягнень учнів 3 цифрового читання. Близько 8 відсотків студентів у 16 країнах-учасницях ОЕСР досягли найвищого рівня з цифрового читання. Учні виявилися спроможними оцінити інформацію з декількох веб-джерел, скласти оцінку 3 погляду достовірності та корисності прочитаного, пересуватися між сторінками тексту автономно і ефективно та ін. Але є значні відмінності між країнами: більше 17 відсотків учнів Кореї, Нової Зеландії та Австралії виконували завдання, досягаючи самого високого рівня, в той самий час як кількість учнів Чилі, Польщі та Австрії склала менше ніж 3 проценти [20].

Вітчизняний процес розвитку моніторингу якості освіти, зокрема у галузі IКT, реалізується як на національному, так і на міжнародному рівнях. У квітні 2010 року відповідно до наказу Міністерства освіти і науки, молоді та спорту України №139 від 23.02.2010 р. «Про дистанційне моніторингове дослідження рівня сформованості у випускників загальноосвітніх навчальних закладів навичок використання інформаційно-комунікаційних технологій у практичній діяльності» [4] було здійснено моніторинг інформатичної компетентності, у якому взяли учать понад 2000 учнів із усіх областей України. У 2012 році з метою «вивчення стану створення сучасного навчального середовища у загальноосвітніх навчальних закладах України, впровадження в навчально-виховний процес інформаційно-комунікаційних технологій» [10] МОН України спільно з Інститутом інноваційних технологій і змісту освіти в Україні було розпочато Всеукраїнське моніторингове дослідження «Стан впровадження інформаційно-комунікаційних технологій у загальноосвітніх навчальних закладах» [12]. Дослідження терміном 2012-2015 рр.., хід якого триває, одним із завдань має дослідити інформаційно-комунікаційну компетентність учасників навчального процесу. На I етапі (2012 р.) у моніторингу взяли участь 13394 респонденти, 3 них: вчителі інформатики - 1470; вчителі-предметники - 8820; учні 9-х класів - 1552; батьки учнів 9-х класів - 1552. У 2007 і 2011 роках Україна стала учасницею масштабного міжнародного дослідженні, що проводить Міжнародна асоціація оцінювання навчальних досягнень IEA - TIMSS (Trends in International Mathematics and Science Study) - Міжнародного дослідження якості природничо-математичної освіти. Хоча це дослідження не лежить у площини IKT, залучення України до міжнародних моніторингових досліджень $є$ важливим фактором розвитку національної системи моніторингу i, як іiі складової, моніторингу впровадження IКТ у загальноосвітніх навчальних закладах. 


\section{4. ВИСНОВКИ ТА ПЕРСПЕКТИВИ ПОДАЛЬШИХ ДОСЛІДЖЕНЬ}

Поданий матеріал дає нам змогу зробити певні узагальнення та висновки, які полягають у тому, що:

- у світовому освітньому просторі позначилася тенденція до моніторингових досліджень 3 IКТ, метою яких є визначення не тільки кількісних, а якісних показників. Моніторинг IК-компетентностей учнів визначений міжнародною i вітчизняною педагогічною спільнотою як необхідний інструмент для вимірювання ефективності шкільної освіти в галузі IКТ, інтерпретація результатів якого сприяє підвищенню іiі якості;

- моніторингові дослідження ІК-компетентності мають здійснюватись на засадах компетентістного та базуватись на практико-орієнтованому підходах до навчання;

- моделювання процесу моніторингу ІК-компетентності учнів можна розглядати у двох напрямках: як такий, що визначає рівень сформованості знань умінь, навичок, особистісних ставлень та ціннісних орієнтирів у галузі IКТ та здатність їх застосовувати в процесі навчання і життя, так і той, що вимірює рівень ІК-компетентності, необхідний у певній навчальні дисципліні.

- перспективним напрямом розвитку процесу моніторингу ІК-компетентності учнів для впровадження у вітчизняну практику можна визначити створення концепції моніторингових досліджень ІК-компетентності учнів як системної i систематичної процедури та як складової системи моніторингу якості освіти.

\section{СПИСОК ВИКОРИСТАНИХ ДЖЕРЕЛ}

1. Біла книга національної освіти України / Акад. пед. наук України; за ред. В. Г. Кременя]. - К., 2009. - 185 с.

2. Державний стандарт початкової загальної освіти [Електронний ресурс] / [затвердж. постановою Кабінету Міністрів України від 20 квітня 2011 р. № 462] // Офіційний веб-портал МОН України. Режим доступу: http://www.mon.gov.ua/ua/often-requested/state-standards/

3. Державний стандарт базової і повної загальної середньої освіти [Електронний ресурс] / [затвердж. постановою Кабінету Міністрів України від 23 листопада 2011 р. № 1392] // Офіційний веб-портал MOH України. - Режим доступу: http://www.mon.gov.ua/ua/often-requested/state-standards/

4. Інформаційний збірник Міністерства освіти і науки України / засн . МОН України; голов . ред . О . В . Єресько. - К . : Видавництво «Педагогічна пресса ». - Тричі на місяць . - 2010. - No 19-20-21.

5. Лукіна Т. О., Патрикеєва О. О. Моніторинг якості освіти: теорія та практика / Т. О. Лукіна, О. О.Патрикеєва // Відкрита педагогічна школа. - К.: Плеяди, 2005. - 111 с.

6. Моніторинг рівня навчальних досягнень з використанням інтернет-технологій: монографія / В.Ю. Биков, Ю.М. Богачков, Ю.О.Жук та ін.]. - К.: Пед. думка, 2008. - 127 с.

7. Моніторинг якості освіти: становлення та розвиток в Україні: Рекомендації з освітньої політики / Під заг. ред. О.І. Локшиної]. - К.: “К.І.С.”, 2004. - 160 с.

8. Моніторинг стандартів освіти / за ред. А.Тайджнмана і Т.НевілаПослтвейта. - Літопис, 2003. - 328 c.

9. Морзе Н.В., Кузьмінська О.Г. Формування інформатичних компетентностей учнів середньої школи [Електронний ресурс] / Н.В.Морзе, О.Г. Кузьмінська // Інформаційні технологій і засоби навчання. - 2011 - №3 (23). - Режим доступу: http://journal.iitta.gov.ua/index.php/itlt/article/view/467 Заголовок з екрану.

10. Наказ МОНмолодьспорт України від 17 грудня 2011 № 1431 [Електронний ресурс] // Веб-портал Освіта.uа - Режим доступу: http://zakon2.rada.gov.ua/laws/show/z1851-12 http://osvita.ua/legislation/Ser_osv/26215/

11. Основи стандартизації інформаційно-комунікаційних компетентностей в системі освіти України: метод. Рекомендації / [В.Ю. Биков, О.В.Білоус, Ю.М. Богачков та ін.]; за заг. Ред. В.Ю. Бикова, О.М. Спіріна, О.В. Овчарук. - К.: Атіка, 2010. - 88c.

12. Узагальнені статистичні матеріали моніторингового дослідження «Стан впровадження інформаційно-комунікаційних технологій у загальноосвітніх навчальних закладах» I етап 
[Електронний ресурс] // Офіційний веб-сайт Інституту інноваційних технологій і змісту освіти MOH України. - Режим доступу: http://iitzo.gov.ua/monitorynhove-doslidzhennya-stanuvprovadzhennya-informatsijno-komunikatsijnyh-tehnolohij-u-zahalnoosvitnih-navchalnyh-zakladah-u2012-2015-rokah/

13. Directive 2007/65/EC of the European Parliament and of the Council of 11 December 2007 amending Council Directive 89/552/EEC on the coordination of certain provisions laid down by law, regulation or administrative action in Member States concerning the pursuit of television broadcasting activities, Official [Electronic $\quad$ resource]. $\quad-\quad$ Mode of http://ec.europa.eu/avpolicy/info_centre/library/legal/index_en.htm

14. Feasibility study for the PISA ICT literacy assessment,. / [Marylou Lennon, Irwin Kirsch, Matthias Von Davier, Michael Wagner, Kentaro Yamamoto]. - [Electronic resource]. - 2003. - Mode of access: http://eric.ed.gov/?id=ED504154

15. Fraillon, J., Schulz, W., \& Ainley, J. (2013). International Computer and Information Literacy Study: Assessment framework. [Electronic resource]//Amsterdam: IEA. - Mode of access: http://www.iea.nl/?id=303

16. Framework for 21st Century Learning, 2010. [Electronic resource]. - Mode of access: http://www.p21.org/index.php?option=com_content\&task=view\&id=254\&Itemid=119

17. Key Data on Learning and Innovation through ICT at School in Europe 2011 c. 96, C. 124. http://eacea.ec.europa.eu/education/eurydice/documents/key_data_series/129EN.pdf

18. Knowledge and skills for life. First results from ODCE programme for international student assessment PISA 2000, [Electronic resource] // OECD. - 2001. - Mode of access: http://dx.doi.org

19. PISA Computer-Based Assessment of Student Skills in Science, 2010. [Electronic resource]. - Mode of access: http://browse.oecdbookshop.org/oecd/pdfs/free/9810041E.PDF

20. PISA 2009 Results: Students on Line: Digital Technologies and Performance [Electronic resource] // OECD. - 2011. - Mode of access: http://dx.doi.org/10.1787/9789264112995-en

21. The PISA framework for assessing ICT literacy: report of the ICT expert panel, April 2003. [Electronic resource]. - Mode of access: http://browse.oecdbookshop.org/oecd/pdfs/free/

Матеріал надійшов до редакиї 19.12.2013 p.

\title{
ИНФОРМАЦИОННО-КОММУНИКАЦИОННАЯ КОМПЕТЕНТНОСТЬ УЧЕНИКОВ КАК АСПЕКТ МОНИТОРИНГА (ОПЫТ МЕЖДУНАРОДНЫХ СРАВНИТЕЛЬНЫХ ИССЛЕДОВАНИЙ ОЕСD И ІЕА)
}

Гриценчук Елена Александровна

научный сотрудник Информационно-аналитического отдела педагогических инноваций Институт информационных технологий и средств обучения НАПН Украины, г. Киев, Украина gritsenchuk@iitta.gov.ua

\begin{abstract}
Аннотация. В статье отражен опыт международных организаций: Международной ассоциации оценивания учебных достижений (The International Association for the Evaluation of Educational Achievement - IEA ) и Организации по экономическому сотрудничеству и развитию ОЭСР (Organisation for Economic Cooperation and Development - OECD) по мониторинговым исследованиям информационно - коммуникационной компетентности (ИК - компетентности) учащихся общеобразовательных учебных заведений; представлен анализ общих подходов к мониторинговым исследованиям ИК - компетентности учащихся в странах Европы на современном этапе. Определены особенности, общие тенденции и перспективные пути развития.
\end{abstract}

Ключевые слова: информационно-коммуникационная компетентность (ИКкомпетентность) учащихся; мониторинг; общее среднее образование. 


\title{
STUDENTS' INFORMATION AND COMMUNICATION COMPETENCE AS AN ASPECT OF MONITORING (OESD AND IEA INTERNATIONAL COMPARATIVE STUDY EXPERIENCE)
}

\author{
Olena O. Grytsenchuk \\ researcher of the Informational and analytical department for pedagogical innovations \\ Institute of Information Technologies and Learning Tools of NAPS of Ukraine, Kyiv, Ukraine \\ gritsenchuk@iitta.gov.ua
}

\begin{abstract}
The article deals the experience of the The International Association for the Evaluation of Educational Achievement - IEA and the Organisation for Economic Cooperation and Development - OECD in monitoring studies of students' information and communication competence ( IC - competence ) of secondary schools, presented an analysis of common approaches to monitoring studies IC - competence of pupils in Europe at the present stage. There are identified peculiarities, common trends and future development.
\end{abstract}

Keywords: pupils' information and communication competence (IC-competence); quality monitoring; general secondary education.

\section{REFERENCES (TRANSLATED AND TRANSLITERATED)}

1. White paper of national education of Ukraine / Acad. ped. Sciences of Ukraine, ed. V.G. Kremen ]. - K. 2009. - 185 p. (in Ukrainian)

2. Primary education state standards [online] / [approved by. Cabinet of Ministers of Ukraine, April 20, 2011 № 462 ] // Official web portal Ministry of Education and Science of Ukraine. - Available from: http://www.mon.gov.ua/ua/often-requested/state-standards/. (in Ukrainian)

3. Secondary education state standards [online] / [ approved by. Cabinet of Ministers of Ukraine of november 23, 2011 № 1392 ] // Official web portal Ministry of Education and Science of Ukraine. Available from: http://www.mon.gov.ua/ua/often-requested/state-standards/.(in Ukrainian)

4. Information digest, Ministry of Education and Science of Ukraine / Education of Ukraine, Chairman. red. O V. Yeresko. - K.: Publishing House "Educational Press." - Three times a month. - 2010. - No 19-20-21. (in Ukrainian)

5. Lukina T.O., Patrikeeva O.O. Quality of monitoring education: theory and practice / T. O. Lukina, O.O. Patrykeyeva // Vidkryta pedagogichna shkola. - Kyiv: The Pleiades, 2005. - 111 p. (in Ukrainian)

6. Monitoring the evaluation of educational achievement using Internet technologies: monograph / V. Bykov, Y. Bohachkov, U.O.Zhuk et al.]. - K. Ped. dumka, 2008. - 127 p. (in Ukrainian)

7. Monitoring education quality: development in Ukraine: educational policy recommendations / O.I.

Lokshina ]. - K.: " KIS ", 2004. - 160 p. (in Ukrainian)

8. Monitoring the standards of education / ed. A.C. Tuijman and N.T. Posltethwaite - - Litopys, 2003. - 328 p. (in Ukrainian)

9. Morse N.V., Kuzminska O.G. Formation informatychnyh competencies high school students [online] / N.V.Morze , O.G. Kuzminska // Information technology and training. - 2011 - № 3 ( 23). - Available from: http://journal.iitta.gov.ua/index.php/itlt/article/view/467 - Title screen. (in Ukrainian)

10. Decree of Ministry of Education and Science of Ukraine, 17 December 2011 № 1431 [online] // Web portal Osvita.ua - Available from: http://zakon2.rada.gov.ua/laws/show/z1851-12 http://osvita. ua/legislation/Ser_osv/26215/. (in Ukrainian)

11. Fundamentals of standardization of information and communication competencies in the education system of Ukraine: recommendations / [ VU Bykov, O.V.Bilous, Y. Bohachkov et al .] Chairman. red. V. Bykov, O.Spirin, O.Ovcharuk. - K.: Atika , 2010. - 88 p . (in Ukrainian)

12. Generalized statistical material of monitoring study "Status of implementation of ICT in secondary schools ", I-st ph. [online] // The official web site of Institute of Innovative Technology and Education Science of Ukraine. - Available from: http://iitzo.gov.ua/monitorynhove-doslidzhennya-stanuvprovadzhennya-informatsijno-komunikatsijnyh-tehnolohij-u-zahalnoosvitnih-navchalnyh-zakladah-u2012-2015-rokah/. (in Ukrainian)

13. Directive 2007/65/EC of the European Parliament and of the Council of 11 December 2007 amending Council Directive 89/552/EEC on the coordination of certain provisions laid down by law, regulation or administrative action in Member States concerning the pursuit of television broadcasting activities, 
Official [online]. - Available from: http://ec.europa.eu/avpolicy/info_centre/library/legal/index_en.htm. (in English)

14. Feasibility study for the PISA ICT literacy assessment,. / [Marylou Lennon, Irwin Kirsch, Matthias Von Davier, Michael Wagner, Kentaro Yamamoto]. - [online]. - 2003. - Available from: http://eric.ed.gov/?id=ED504154. (in English)

15. Fraillon, J., Schulz, W., \& Ainley, J. (2013). International Computer and Information Literacy Study: Assessment framework. [online] // Amsterdam: IEA. - Available from: http://www.iea.nl/?id=303. (in English)

16. Framework for 21st Century Learning, 2010. [online]. - Available from: http://www.p21.org/index.php?option=com_content\&task=view\&id=254\&Itemid=119. (in English)

17. Key Data on Learning and Innovation through ICT at School in Europe 2011 [online]. - Available from: http://eacea.ec.europa.eu/education/eurydice/documents/key_data_series/129EN.pdf. (in English)

18. Knowledge and skills for life. First results from ODCE programme for international student assessment PISA 2000, [online] // OECD. - 2001. - Available from: http://dx.doi.org (in English)

19. PISA Computer-Based Assessment of Student Skills in Science, 2010. [online]. - Available from: http://browse.oecdbookshop.org/oecd/pdfs/free/9810041E.PDF (in English)

20. PISA 2009 Results: Students on Line: Digital Technologies and Performance [online] // OECD. - 2011. Available from: http://dx.doi.org/10.1787/9789264112995-en (in English)

21. The PISA framework for assessing ICT literacy: report of the ICT expert panel, April 2003 [online]. Available from: http://browse.oecdbookshop.org/oecd/pdfs/free/ 